\title{
STUDENTS' PERCEPTION TOWARDS FLIPPED CLASSROOM APPROACH IN THE ISLAMIC AND ASIAN CIVILISATION STUDIES (TITAS)
}

\author{
${ }^{1}$ Rafa Nurafida Binti Abdul Rahim \\ nurafa0324@gmail.com \\ ,*Dr Mohammad Ali Al-Saggaf \\ mohammad_ali@msu.edu.my
}

Received: 25.01.2021 • Accepted: 01.03.2021 • Published: 31.03.2021 • Final Version: 31.03 .2021

\begin{abstract}
Flipped classroom is an active, student-centered approach that has been developed to enhance the quality of time in the classroom. This study investigates the perceptions of third year Bachelor in Teaching English as a Second Language (BTESL) and Bachelor in Accounting (BIA) students in a Higher Education Institute, Malaysia. It aims to examine the students' perceptions towards the use of flipped classroom approach in Islamic Civilisation and Asian Civilisation subject (TITAS) and to identify whether there is any significant difference between the perceptions of two groups of students with different educational backgrounds. This study involves 124 respondents consisting of $82(66.1 \%)$ third year BTESL students and $42(33.9 \%)$ BIA third year students. It adopted a quantitative research design using a survey method for data collection. The questionnaire was adapted from previous studies as the instrument for this study. Data were analysed through SPSS software and were interpreted through descriptive analysis and an Independent sample T-test. The findings show the majority of BTESL and BIA students perceived the usefulness of flipped classroom implementation in TITAS class positively. However, the study findings also revealed that there is no significant difference between the perceptions of BTESL and BIA students. Consequently, the outcomes were inferred that students perceived flipped classroom approach in TITAS class to be useful and there is no significant difference between the perceptions of the two groups of students with different educational backgrounds.
\end{abstract}

Keywords: flipped classroom; Bloom's taxonomy; student's perception; TITAS; education.

\section{INTRODUCTION}

Increased use of information technology in classrooms was observed in the $21^{\text {st }}$ century. Most students use mobile phones, iPad and other digital devices as their teachers for their

\footnotetext{
*Corresponding Author: mohammad_ali@msu.edu.my
} 
studies. They prefer to access information on the internet as it is more abundant, easier to reach, and more advanced, (Paige, Hickok, and Patrick, 2004, p. 11) as cited in Eppard \& Rochdi (2017). Flipped learning is one of the methods that integrate technology into the classroom, making it increasingly popular in the field of education. The flipped classroom has also been found to be a creative and innovative teaching method as it enhances students' engagement in the classroom, especially in terms of interaction with peers and teachers. However, there were unfavourable feedbacks from students towards the implementation of Flipped classroom approach. For instance, some students were unable to engage in flipped learning due to lack of guidance from the instructor during online lectures and time-constraints (Almodaires, Alayyar, Almsaud, \& Almutairi, 2018).

In particular, the flipped classroom model addresses students and educator relationship in the learning contact. Direct instruction, traditionally in the form of a lecture which is moved from the group space to the individual space (Jensen, Kummer \& Godoy, 2015; McLean Attardi, Faden \& Goldszmidt, 2016). In flipped classrooms, students are involved in learning activities both inside and outside the classroom, Bishop and Verleger (2013). Roehl et al., 2013; Bergmann \& Sams,2014 stated that flipped learning enables the introduction of flexible pedagogy that provides varied needs of students, and enhances student participation and engagement in the learning activities and processes. According to Deslauriers, Schelew and Wieman (2011) and McLaughlin et al. (2013) as cited in Smallhorn (2017) reported that higher student attendance rates and greater student engagement were observed in flipped classroom. Berett (2012) stated that students in the flipped section made gains at twice compared to the rate of students in the traditional section. Zainuddin and Perera (2017) found out that the flipped classroom cultivates higher autonomous learning and better interaction among peers. Studies above showed that a flipped classroom helps students to be active learners despite class size. Based on Danker (2015), the flipped classroom setting helped to switch passive learning into more active and student-centered learning through the use of technology.

Furthermore, Mata Pelajaran Umum (MPU) subject or General studies is designed to enhance not only students' knowledge but also their skills that go beyond academic disciplines. In an MPU subject, students are required to organize an activity outside the classroom and projects that will be supervised by instructors or lecturers (Buku Garis Panduan Pengajian Umum (MPU) Edisi Kedua 2016). Tamadun Islam dan Tamadun Asia Tenggara or Islamic Civilisation and Asian Civilisation studies are one of the MPU subjects that need to be taken by all tertiary education students in Malaysia. MPU subjects are known as balanced and wholesome combination subjects as they implement collaborative learning skills, leadership skills, project management skills, and experiential learning (Mata Pelajaran Umum, 2018). Besides, MPU subjects adopt learning and teaching approaches that are both students-centered and also research-led-teaching where most of the time, classroom time is focused on the implementation of higher-level learning.

Hence, the current study investigates the perceptions of third year Management and Science University Bachelor students from Bachelor in Teaching English as a Second Language (BTESL) and Bachelor in Accountancy (BIA) towards Flipped Classroom Approach based on their learning experiences in MPU subject (TITAS) Tamadun Islam dan Tamadun Asia Tenggara or Islamic Civilisation and Asian Civilisation Studies class. This is a comparative 
study which has been carried out to the students from two different faculties with different backgrounds of education.

\subsection{PROBLEM STATEMENT}

Flipped learning has been broadly adopted by educationists in numerous fields. Although most of previous studies showed that students give positive feedbacks on flipped classroom approach but some students also showed less interest in flipped classroom approach. It has been discovered that students from different backgrounds of education perceive the implementation of flipped classroom approach differently. Triantafyllou and Tiniceko (2014) as cited in Ajayi, Iahad, Ahmad, \& Yusof (2017) introduced flipped learning approach in a statistical class for Media Technology students, at the University Copenhagen. The researchers observed that students in the discipline which is more of Art and Humanities course lack interest in the statistical course when compared to other students with a science background. Based on the previous experience of respondents, which was affected by inaccurate usage of the approach by instructors, (Chan, Lam, \& $\mathrm{Ng}$, 2020) argued that flipped learning approach is perceived to be effective but not well accepted among students in Malaysia. Studies that compare two different groups of students' perceptions with different education backgrounds towards the implementation of flipped classrooms were found to be limited. Therefore, to provide a more detailed investigation on students' perceptions of the use and the implementation of the flipped classroom model in higher education, a study has been carried out in a Higher Education Institute in Malaysia between two different groups of participants from different faculties and courses in MPU subject, TITAS class to minimize the research gap.

\subsection{Higher Education in Malaysia}

Flipped learning has been adopted in most of the educational institutions in Malaysia into their pedagogy to reach the maximum potential of the students which is aligned with the Malaysia Education Blueprint (Al-Saggaf et. al. 2020; Azar \& Sahar 2020; Goyena \& Fallis, 2019). Flipped learning is a systematic approach for educators to integrate a technological teaching atmosphere. In line with this development, Malaysia's Ministry of Education has efficiently made a step forward by introducing the Malaysia Education Blueprint (2013) containing 11 operational changes to the Malaysian education system vision (Al Aqad, M. H. 2020; Subon, F., Unin, N., \& Sulaiman, N. H. B. 2020; Goyena, \& Fallis, 2019). The importance of Information and Communication Technology (ICT) was underlined in the $7^{\text {th }}$ shift in the Malaysia Higher Education Blueprint (2015-2025), ICTbased learning is outlined and it is known as Globalized Online Learning. Enhancing the learning experience of students in the design and construction of programmes by broadening industry collaboration is one of the key initiatives of the Ministry to develop a more holistic and integrated curriculum. Flipped learning is one of the teaching methods that have been implemented in teaching practices since the occurrence of blended learning was introduced (Zainuddin \& Attaran, 2016). From a study conducted at Sunway University, Danker (2015) explored that a flipped learning is capable of remodeling a large class into one active-learning class. A study was focused on the Technical and Vocational Education and Training (TVET) students and it was found that flipped learning creates 
positive impacts on the second language learners (Singh et al., 2017). Moreover, flipped classroom has been implemented in most of the higher education institutions. Burhan, Tamuri, and Nordin (2015) stated the learning materials in the TITAS course equipped in various contexts such as fieldwork projects, online, notes, blogging, video making and interactive activities. There are more studies that explained the implementation of flipped classrooms in Malaysia education. The elements of a flipped classroom which are online learning platforms and student's engagement have been discussed and designed in Malaysia Education Blueprint. Hence, this study attempts to find answers to the following research questions

1) How do BTESL and BIA third year students perceive the use of the flipped learning approach in terms of its usefulness based on their learning experiences in TITAS class?

2) What are the differences between BTESL and BIA third year students' perceptions from their learning experiences toward Flipped classroom approach in TITAS class?

\subsection{Theoretical Framework}

\section{Bloom's taxonomy. .}

In 2001, the original taxonomy was reviewed and the names of the categories were changed from nouns to verbs. Bergmann and Sams (2014) argued that teachers spend more time giving importance in remembering, understanding and application on what has been learned. Teachers spend less time in assessing, evaluating and improving students' higher thinking levels (Zainuddin \& Halili, 2016). The study of flipped classrooms was based on the revised Bloom's cognitive domain taxonomy theory by Benjamin Bloom. This taxonomy imparts six learning stages, and the explanations are orchestrated from the lowest to the highest level. According to Nederveld and Berge (2015) as cited in Zainuddin \& Halili (2016) in flipped learning, classroom time is centered on usage and higher-level learning, instead of tuning in to lectures and other lower-level cognitive activities.

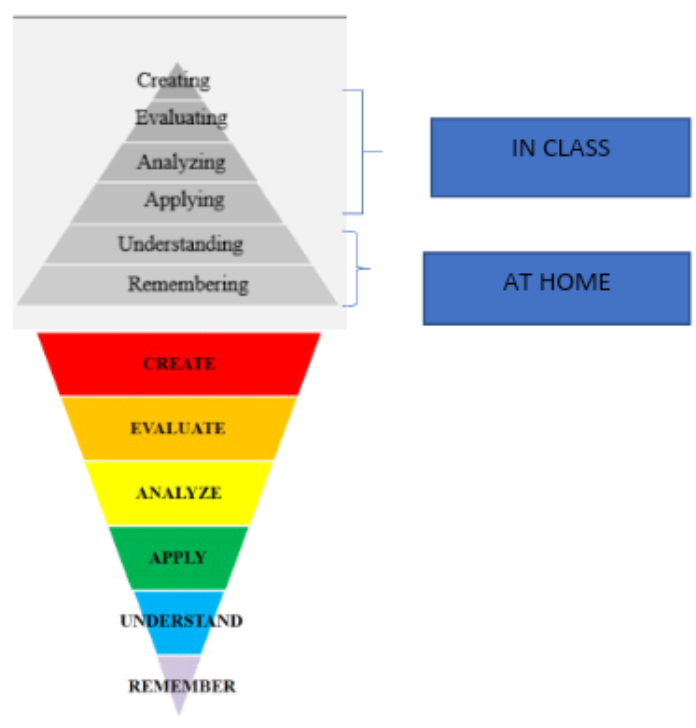


Figure 1. Bloom's Taxonomy Revised and Inverted (Bergmann \& Sams, 2014, p. 34)

Remembering and understanding will be the lowest levels of cognitive domain practiced out of the lesson hour in flipped classroom implementation (Krathwohl \& Anderson, 2010, as cited in Zainuddin \& Halili, 2016). The students centered on higher forms of cognitive work such as applying, analyzing, evaluating and creating during the class session (Zainuddin \& Halili, 2016). Picture above outlines the level of students' learning within the flipped learning based to Bloom's revised taxonomy.

\section{Constructivism}

Vygotsky described learning as a process that occurs when learner is facilitated by others who are more advanced in learning skills and that learning is integrated by collaboration within the learner's Zone of Proximal Development (ZPD) (Eppard \& Rochdi, 2017). The zone of proximal development (ZPD) is defined by Vygotsky (1978) as, "the difference between the actual level of development as determined by independent problem solving and the level of potential development as determined by problem solving under adult supervision, or in collaboration with more competent peers". In simple words, learning occurs when a difficult problem is being solved by a student working with another skilled or with peers (cited in Eppard \& Rochdi, 2017). In the flipped classroom approach, students will be given problem- based solving tasks where they need to apply the knowledge or information, they learned through online noted or by watching videos outside of the classroom. Students need to work individually or in a team with teacher guidance for them to solve the problems. Study shows when students are taught based on their specific learning style that may be independent, collaborative or autonomous (Eppard \& Rochdi, 2017; Yassin et al., 2020).

\section{Technology Acceptance Model (TAM)}

"Intention to adopt a new system or technology" is what TAM theorizes users (F. D. Davis). It is decided by two concepts which are perceived usefulness and perceived ease of use. Perceived usefulness "the degree to which an individual believes that using a particular system would improve his or her performance" and it is found that attitudes towards use, intention to utilize a new system will be affected by the conviction on the usefulness of new technology as it is one of the powerful factors of actual system usage, F. D. Davis as cited in Yoshida (2016). Three main clusters have been identified by F. D. Davis which are: job effectiveness, productivity and time savings, and significance of the system to one'se job.

\section{Mastery learning theory}

Mastery learning was first introduced in the 1920s and it was popularized by Benjamin Bloom in the 1960s. Benjamin Bloom argued that students can ace any content if they are provided with sufficient time and assistance. Mastery learning is where students learn at their own pace. The key elements of mastery learning are;

Students work individually or in a small group at a suitable pace 
The instructor or teacher assess the students formatively and measures student's comprehension.

Students demonstrate mastery of the objectives of summative assessments. Remediation is offered for students who don't ace a given goal.

(Sams \& Washington, 2012)

Mastery model educates the students to be responsible in their learning, provides chances for remediation, allows for various means of learning content, offers numerous opportunities to denote understanding and changes the position of the instructor. Instead of standing in front of the class delivering information, a teacher will spend their time helping students, leading small groups, and working with the students who struggle to engage in the class (Sams \& Washington, 2012)

\section{LITERATURE REVIEW}

\subsection{Flipped classroom}

Jonathan Bergman and Aaron Sams were the pioneer who first applied the Flipped classroom model in the area of chemistry, 2007, according to the related literature (Urfa,2008). The flipped classroom is a mix of an altered classroom that hones both interior and exterior practices where students take obligation for the out-of-class behaviours by observing recordings, going to websites related to the lesson, tuning in to audios and reading references (Alsowat, 2016). The Flipped Classroom model is a blended learning model that moves curriculum delivery in a conventional classroom setting to an online platform that converts learning activities designed for students at home to conventional classrooms and enables these activities to be expanded and performed under the supervision of the teacher (Demiralay and Karataş, 2014). A flipped class has multiple conflicting definitions, with no single description (Educause, 2012).

The key components of flipped classes are identified by several scholars and practitioners:

1) Enhanced student interaction

2) Collaboration and team learning

3) Moving from a community learning space to a more individualized one

4) Emphasizing teacher as an organizer, facilitator, and coach instead of master

5) Emphasizing students taking control of learning (self-motivated learning)

6) Use constructive learning methods (activities, discussion, feedback) rather than passive lectures.

Hall \& DuFrene, (2016); Flipped Learning Network, (2014); Sherrow et al., (2016) as cited in Garner \& Chan, (2019) 


\subsection{Students perceptions}

Perception is a view or an attitude of one's towards something which is also known as a reaction. It is a special way to perceive phenomena through the perception of sensory knowledge based on experience, information processing, and mental models' formation (M. Susan,2012).

\section{Perceived usefulness}

Fred Davis defined Perceived Usefulness (PU) as one of autonomous builds within the Technology Acceptance Model (TAM). It is a degree to which an individual believes his or her job performance will be enhanced by using a particular method or system (Davis, 1989). Lee, Y. H., Hsieh, Y. C., \& Chen, Y. H., (2013) as cited in I. Ajayi, (2017) stated that attitude was observed to be affected by PU construct in proceeding the idea to use the flipped classroom. In instructional design, the perceived usefulness of flipped learning does not only consist of technology-related usefulness but also the usefulness of the learning process (Yoshida, 2016). Flipped learning is not a replacement word for online video courses, but it's a blended direct instruction with constructivist learning, B. Tucker as cited in Yoshida, (2016) and to focus on the whole learning to guarantee the quality of flipped learning is important.

\section{Online Learning platform}

Technology has been a great opportunity for educators to design various teaching methods and activities for the learning process. Revere \& Koach, (2011, p. 123) as cited in L.Ogden (2015) argued that technology can promote student participation in the learning process when it is used correctly, which many students acknowledge the advantages and research has shown that technology helps to decrease retention, increase learning outcomes and boost student satisfaction. Online notes and educational videos in the Flipped classroom introduce the students to E-learning where they will be able to receive the content of the lesson more easily and they do not need to buy plenty of books or use printed materials. Based on the previous researchers it seemed that implementing technology in student's learning has pros and cons. Despite all the positive feedbacks on using online platform learning in a flipped classroom. Some articles revealed the limitations of implementing technology in flipped learning. Internet connectivity was the limitation of implementing online platform learning (Sinouvassane \& Nalini, 2016). However, technology is not a new word, especially in this $21^{\text {st }}$ century. It gives a great impact on students learning as students get to explore and acquire knowledge in depth. As stated by Evseeva \& Solozhenko (2015), the use of technology in the flipped classroom increased students' motivation and enhances their academic performance. This demonstrates that 
students are taking on responsibilities for their learning after the incorporation of the flipped classroom in their learning process.

\section{Students engagement}

The level of consideration, interest, intrigued, positive thinking, and energy that students pass on when they are learning and their level of amplification in inspiration for learning is what we call students' engagement in instruction (The Glossary of Education Reform, 2016). Based on Borg \& Shapiro (1996) as cited in Inan, Balakrishnan, \& Refeque (2019) if the teaching method is suitable with students learning style only then it is called proper management because any kind of mismatch would cause lesser engagement in students and destitute learning experience. Students' engagement in classroom learning is an important element that should be taken into consideration. According to the past researchers, most of them received positive feedback from the students as they get to work with a peer, interact and discuss with peers. It creates a meaningful learning environment for the students as they feel more active and productive in the flipped class. As mentioned by Tazijan et al (2016) flipped classroom promotes the students into an active learning environment as it yields to students centered activities. When students are engaged in learning, they will obtain a better understanding and makes them more focused in class. The implementation of a Flipped classroom in online project-based learning also enhances their critical thinking and communication skills (Shih \& Tsai, 2017). As contended that students prefer to be in a flipped classroom because they felt that they are more engaged as they attained individual attention and direction from their lecturers in the flipped classroom. However, it contradicts a study conducted by Almodaires, Alayyar, Almsaud, \& Almutairi (2018) who explored that students perceived some limitations in terms of guidance from the instructor during online lectures and time-constraint. Furthermore, another negative feedback was obtained from students where some students mainly part-time students could not participate fully in class because of their circumstances which were studied by (Zainuddin \& Attaran, 2016). Also mentioned that some students failed to engage in flipped classroom learning due to inaccurate application by the instructors (Chan, Lam, \& Ng, 2020). Based on Vygotsky's constructivism theory, it was eloquently stated by Eppard \& Rochdi (2017) research indicates that students learned best when are taught based on their specific learning style that may be dependent, collaborative, or autonomous.

\subsection{Factors influencing flipped classroom}

\section{Weak Independent learning capacity of students}

Independent learning is known as self-management learning which encourages learner's autonomy and independence. According to Win (2011) as cited in Li (2019) independent learning ability mainly denotes learning with networks as students can become more efficient in learning through information technology. In the traditional teaching approach, students will always be 'spoon-fed' by the teacher and they don't have the initiative to explore the knowledge. Students are being too dependent on the teacher and lack consciousness of independent learning. Nevertheless, the teaching style has changed in the internet- knowledge era, and a new teaching style demands that the learning initiative 
should be provided to students instead of teachers who are only mentors and helpers ( $\mathrm{Li}$, 2019).

\section{Low non-intelligence of students}

Non- intellectual is related to cognitive factors that include motivation, emotion, interest, will, goal, need, and character $(\mathrm{Li}, 2019)$. Some students are frail in overcoming challenges which affect their ability to unravel problems. To ensure the effect of autonomous learning in flipped classroom teaching, students need to acquire strong self-management ability ( $\mathrm{Li}$, 2019). Therefore, in flipped classroom model, students are prepared and stimulated by watching videos and at the same time cooperative learning is enlightened. This will eventually develop students' ability to solve problems and face difficulties.

\section{METHODOLOGY}

A quantitative research method was adopted to investigate the perceptions toward Flipped Classroom approach in MPU subject (TITAS) among third-year BTESL and BIA students. The outcome of this research is determined by the numerical content. In the current study, a survey was used to collect the structured data about BTESL and BIA second-year students' perceptions toward Flipped class in MPU subject (TITAS). The questionnaires were distributed through an online platform. This questionnaire was adapted from three different published articles related to students' perceptions on the use of flipped classroom which are Validation of Feedback Questionnaire on Flipped Classroom (FC) Activity by Barua \& Kumar Shiva Gubbiyappa, Hasnain Zafar Baloch (2014), Perception of Undergraduate Students on the Utilisation of Flipped Classroom for Learning in South-West by Onojah, Olumorin, Adegbija, \& Babalola (2019) and Perceived Usefulness of "Flipped Learning" on Instructional Design for Elementary and Secondary Education: With Focus on Pre-service Teacher Education by Yoshida (2016). A five-point Likert scale was used to rate every item in the questionnaire. All the items were measure by using a five-point Likert scale consist of strongly disagree, disagree, neutral, agree and strongly agree. Part 1 consists of three questions on students' demographics background which are age, gender and course (BTESL and BIA). Part 2 consists of 20 questions on students' perceptions towards flipped classroom in TITAS subject. It was separated into two categories part 2(a) and part 2(b) where 10 of the items related to the perception of the students on online learning in a flipped classroom, TITAS subject and another 10 items were on student's engagement in the flipped classroom, TITAS subject.

The collected data were statistically analysed. These surveys emphasize on measuring and counting of the data to obtain the results. The focus of this research is to identify the perceptions among BTESL and BIA third year students and to compare their perceptions on the implementation of Flipped classroom approach from their learning experience in TITAS class. The instruments in this research are more of a rigid style of eliciting and is categorizing responses to questions. Third year students of Bachelor of teaching English as a second language (BTESL) and Bachelor in Accounting (BIA) who have taken Asian civilization and Islamic Civilisation (TITAS) subject are the groups of participants targeted for this study. This particular group of students was chosen because most of them have already taken this subject compared to the first and second-year students. They were also 
chosen because they have different backgrounds of education as BTESL is a course where students are introduced to language and BIA is a mathematics-based course. The total number of BTESL and BIA students in MSU are 580 and 389 respectively. There are 170 BTESL and 61 BIA third year students. However, the total number of third year students from BTESL and BIA who have taken TITAS subject which will be the main focus of this research are 120 and 61. For the selection of participants, the researcher employed the stratified sampling method in this study as two specific subgroups have been highlighted within the population. It was calculated with $95 \%$ of confidence and $5 \%$ margin of error using a sample calculation generator. After the calculation was made, it was shown that a total of 82 BTESL and 42 BIA third year students were required for this study. For the first research question, all the students were taken to present the findings. However, for the second research question which is to compare the perceptions between BTESL and BIA third year students, 40 students from each stratum were randomly chosen to avoid biases.

The pilot study was carried out in research to know about the reliability of the questionnaire (Keat, O. B., Rajaratnam, M. L., \& Yuniardi, M. S.,2020). The Cronbach alpha of the raw items adapted from previous researchers were 0.912 and 0.81 , which showed that the instruments were reliable to use while for the third article, the researcher did not mention the reliability of the instruments. The modified questionnaire was formally piloted with a sample of 34 students and it showed the Cronbach alpha was 0.824 . There were 23 items in total including the demographic background of the respondents. An independent sample Ttest were used to identify whether there is any significant difference between the perceptions of BTESL and BIA third year students.

\section{FINDINGS}

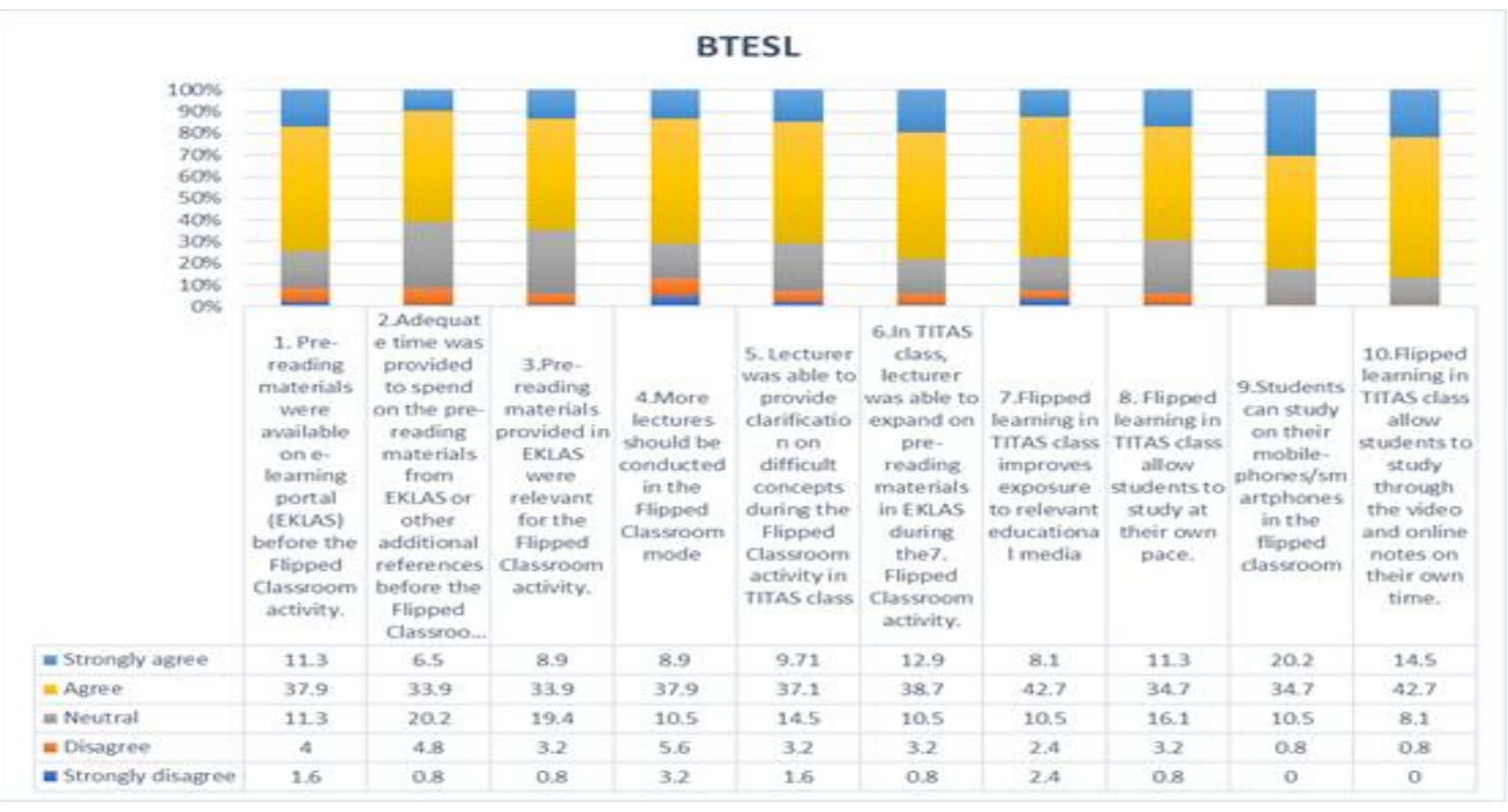

Figure 2. Percentage on students' perceptions towards the use of Online learning platform (BTESL) 


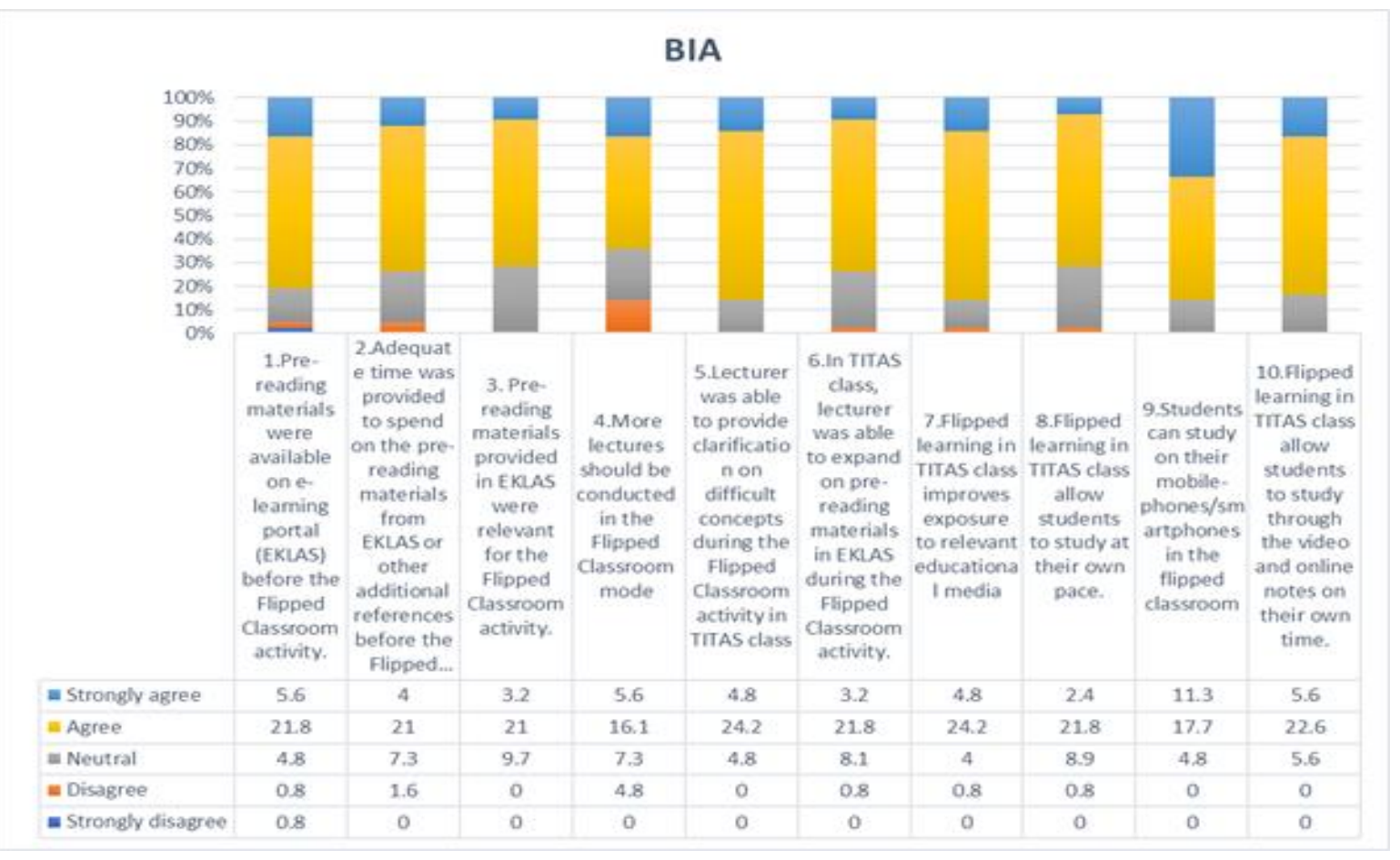

Figure 3. Percentage on students' perceptions towards the use of online learning platform (BIA)

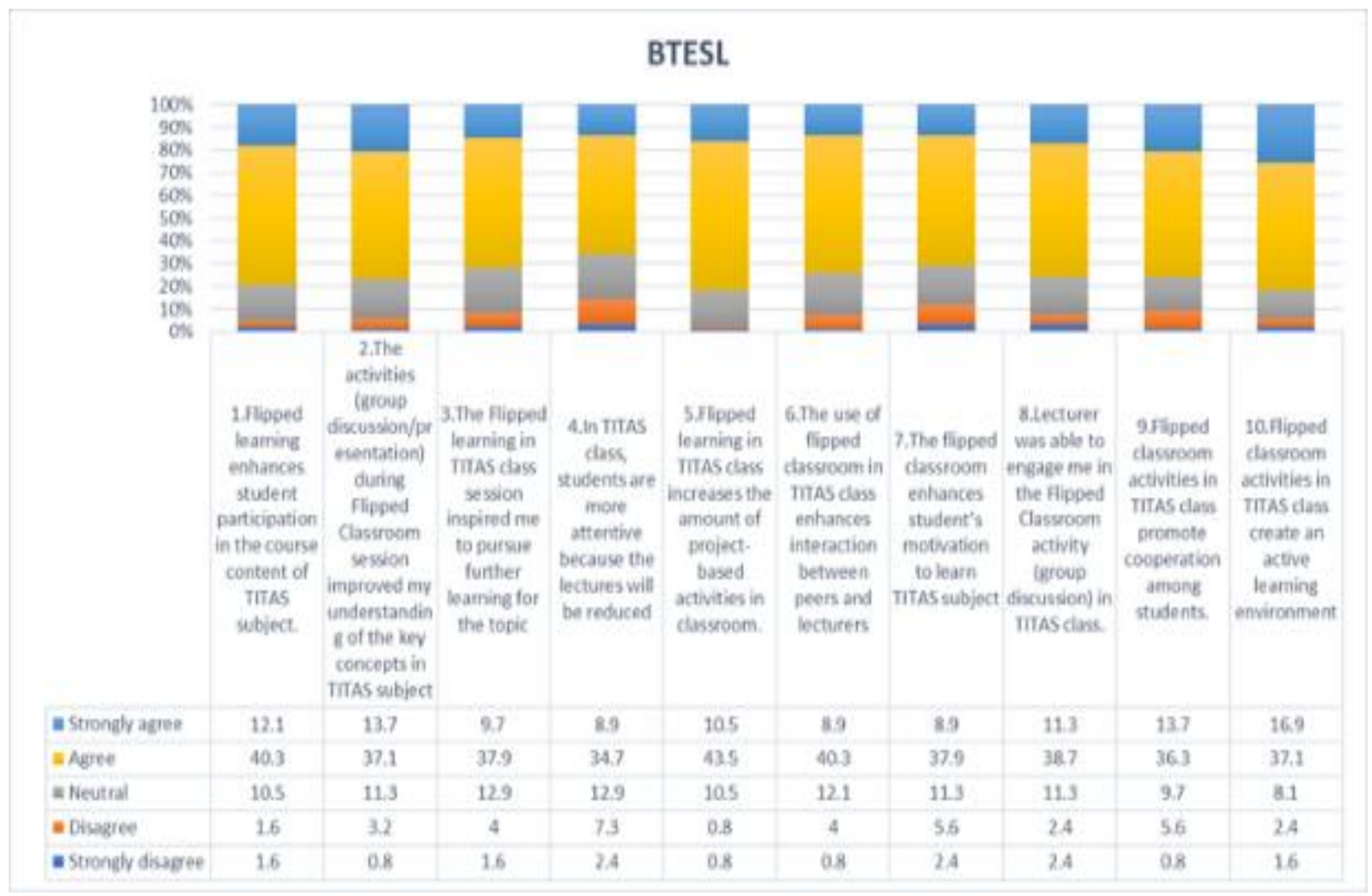

Figure 4. Percentage on students' perceptions towards students' engagement (BTESL) 


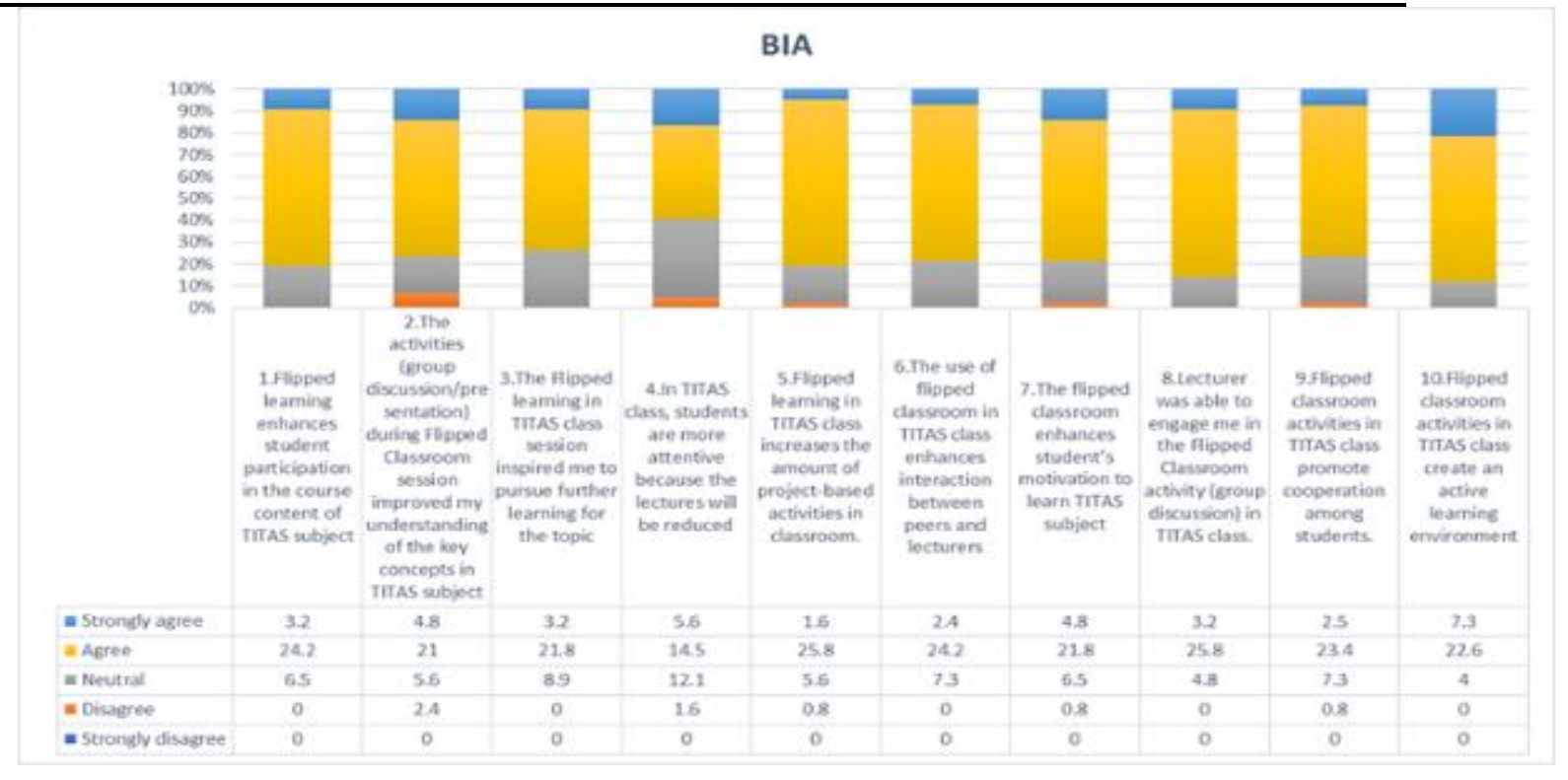

Figure 5. Percentage on students' perceptions towards students' engagement (BIA)

4.1 How do BTESL AND BIA third year students perceive the use of Flipped Learning Approach based on their learning experiences in TITAS class?

According to the item analysis, the researcher could interpret whether the students from both different courses and faculties perceived the use of Flipped classroom in TITAS class positively or negatively. The bar charts illustrated on the BTESL and BIA students' responses showed that the majority of the students chose 'Agree' as their choice for the items. There were only less than $10 \%$ of respondents 'Disagree' and 'Strongly Disagree' for the items online learning and student's engagement. It was observed that from the analysis of each item, although the percentage of 'agree' was the highest for all the items there were some of the respondents selected on 'Neutral', 'Disagree, and 'Strongly Disagree' from both courses.

4.2 What are the differences between BTESL and BIA third year students' perceptions from their learning experiences toward the Usefulness of Flipped Classroom Approach in TITAS class?

For the second research question, an Independent samples T-test was conducted to compare the perceptions on the use of flipped classroom approach in TITAS class for both courses, BTESL and BIA. An equal amount of sample size was presented for both courses to avoid biases and disproportionate sampling. The sample size from each course BTESL and BIA were randomly selected. Based on the tables above, the scores for Bachelor in Teaching English as Second Language (BTESL) are $(\mathrm{M}=75.35, \mathrm{SD}=10.6)$ and Bachelor in Accounting (BIA) $(\mathrm{M}=77.78, \mathrm{SD}=7.06)$ Conditions; $\mathrm{t}(78)=-1.203, \mathrm{p}=0.23$. According to table 4.6.1(B), the p-value of Levene's Test for Equality of Variances is 0.76. The row of output in the Equal variances assumed will be used if the p-value or Sig. is (>0.05) while 
the outputs in the row of Equal variances not assumed will be used if the p-value is $(<0.05)$. Aforementioned, the p-value or Sig. (2-tailed) is 0.232 .

\section{DISCUSSION}

On the whole, based on the results discussed in previous sections it has shown that the third year BTESL and BIA students perceived the implementation of a flipped classroom in TITAS class to be useful in terms of the online learning platform and student's engagement. It was supported by the previous researchers who found that the use of technology increases the student's motivation and allows them to learn at their own pace. Sams \& Washington (2012) discovered that an online learning platform is a great learning tool as the students are becoming more independent in the learning process and explore various ways to find the information they need. Another study conducted by Santikarn, B., \& Wichadee, S. (2018) concluded that the learning environment of Flipped classroom grasp the interest of the students as they gained more positive impacts such as better engagements in activities and autonomous learning skills. Lastly, for the second research question, it has shown that there is no significant difference between the perception of third year BTESL and BIA students. Based on the previous literature, the results showed an opposite outcome of assumption. Thus, the researcher assumed that improvements would show on the population, sample size and data collection.

\subsection{Limitations of the study}

This study faced several limitations that should be elucidated. Firstly, this study has a sample size as it only focuses on students who have taken the specific subject, TITAS and third year students. This study only covers a total of 124 students from two different courses. Plus, small sample size can affect the reliability of a survey's result as it leads to a higher variability. Besides, this research only investigates the student's perceptions in terms of their perceived usefulness in the implementation of the flipped classroom in TITAS class. The data collection method was only focused on the survey method and this could not explain exactly the student's experiences because each student may have been faced a different kind of situations and experiences in the flipped classroom in TITAS class. This research is a quantitative study it only involves structured questions which does not denote the actual occurrence in a generalized form. 


\subsection{Recommendations}

The future researcher can involve students from other courses that have a different educational background and compare their perceptions on the implementation of flipped classroom approach in TITAS subject. To be more specific it is also recommended to compare students from different years of study. Furthermore, it is highly recommended for future researchers to carry out a qualitative research method or mixed-method to look deeper into students' attitude, effectiveness and to acquire richer information on the student's experiences in TITAS class. lastly, it is suggested for future researchers to enlarge on the aspects of the student's perceptions towards the implementation of the flipped classroom into a larger scope of the study.

\subsection{Implication}

The knowledge gained through this study will contribute especially to Higher education Institutes' lecturers and future teachers. It gives insight into the implementation of flipped classrooms specifically in TITAS class. This study can help educators to develop practices that facilitate the implementation of a flipped learning environment in the classroom. Future teachers will be more alert on the creative and strategic teaching methodologies that are aligned with $21^{\text {st }}$-century learning. Besides, lecturers in charge of TITAS subject in a higher education institute specifically can observe the perceptions of two different groups of students towards the use of flipped classroom approach demonstrated in this study to arrange the course outline more strategically by considering the negative responses from the students in certain elements.

Furthermore, it might benefit other higher education institutions in Malaysia to implement flipped classroom approach in MPU subjects. The course outlines designed by a higher education institute for TITAS subject may give a better insight for other Higher education Institutions to remodel or redesign their TITAS course outline to be more strategic in the teaching and learning process to achieve the objectives and components constructed by the Ministry of Education. This study could be an eye-opener for the educators, future educators, and students on what is the real concept of a flipped classroom, the misconception towards flipped classroom which makes the educators avoid flipped classroom approach could be solved. It also enlightens on the importance to know how do students perceive the use of flipped classroom approach in TITAS subject in Higher education Institute.

\section{Conclusion}

Islamic civilization and Asian civilization (TITAS) subjects are one of the important MPU subjects for all the students in Malaysia as it is one of the compulsory subjects to score for the students to graduate. It is not an easy subject that can be written only with prior knowledge. It needs students to read and understand the background of the community, religious belief systems, and cultural diversity in those early civilizations. Plus, it is also a subject that injects students on soft skills and a sense of respect, morality, and mainly human capital development as a citizen. Flipped classroom approach is implemented in MPU subjects and one of it is TITAS class at the Higher education Institute under this study 
to encourage students to share opinions, work collaboratively and boost critical thinking skills. In TITAS class, students usually will be allowed to take charge of their learning and this increases communication and contact time between students and lecturers.

Technology allows universal access to all the online sources for the students as their learning material. To acquire a deeper understanding of the contents of this subject, the online materials will be their lecturer. Furthermore, collaborative learning and projectbased activity in TITAS class are highly implemented to engage the students and create an active learning environment. Online Learning and student's engagement in TITAS class were the main focus in this study to examine how students from two different courses perceived the use of those aspects in the flipped classroom. Besides, their perceptions were also compared to explore whether there is any significant difference between students with different educational backgrounds. As stated above, the students perceived the implementation of the flipped classroom as useful as the majority of the students showed positive responses towards the items; online learning platform and students' engagement. However, there were negative responses obtained from some of the students and that also showed that there are students are having some issues on the online learning platform and their engagement in TITAS class. Those issues may have been discussed by previous researchers such as issues on internet connectivity and inaccurate usage of the approach. Although, majority of the students perceive the implementation of the flipped classroom to be useful as an educator it is a must to consider issues faced by some of the students towards the implementation of the flipped classroom. In conclusion, in this $21^{\text {st }}$-century era, educators are encouraged to take a new step to be more alert on identifying students' learning needs and guide them to higher levels of learning.

\section{REFERENCES}

[1] Al Aqad, M. H. (2020). Contextualization of Social Media and Its Implications on the Audience. In Off and Online Journalism and Corruption-International Comparative Analysis. IntechOpen.

[2] Abdullah, M. Y., Hussin, S., \& Ismail, K. (2019). Implementation of flipped classroom model and its effectiveness on English speaking performance. International Journal of Emerging Technologies in Learning, 14(9), 130-147. https://doi.org/10.3991/IJET.V14I09.10348

[3] Ajayi, I. H., Iahad, N. A., Ahmad, N., \& Yusof, A. F. (2017). A proposed conceptual model for flipped learning. Journal of Theoretical and Applied Information Technology, 95(24), 70497057.

[4] Akareem, H. S., \& Hossain, S. S. (2016). Determinants of education quality: what makes students' perception different? Open Review of Educational Research, 3(1), 52-67. https://doi.org/10.1080/23265507.2016.1155167

[5] Almodaires, A. A., Alayyar, G. M., Almsaud, T. O., \& Almutairi, F. M. (2018). The Effectiveness of Flipped Learning: A Quasi-Experimental Study of the Perceptions of Kuwaiti Pre-Service Teachers. International Education Studies, 12(1), 10. https://doi.org/10.5539/ies.v12n1p10

[6] Alsowat, H. (2016). An EFL flipped classroom teaching model: Effects on English language higher-order thinking skills, student engagement and satisfaction. Journal of Education and Practice, 7(9), 108-121. 
[7] AL-SAGGAF, M., Kader, F. F. ., Alias, A. N. I. ., \& Abdul Raof, N. A. . (2020). Level of Attachment of Malaysian TESL Students Towards Their Cultural Identity. International Journal of Language and Literary Studies, 2(4), 63-82. https://doi.org/10.36892/ijlls.v2i4.458

[8] Andujar, A., Salaberri-Ramiro, M. S., \& Martínez, M. S. C. (2020). Integrating flipped foreign language learning through mobile devices: Technology acceptance and flipped learning experience. Sustainability (Switzerland), 12(3). https://doi.org/10.3390/su12031110

[9] Azar, A. S., \& Sahar, S. A. B. M. (2020). Factors Affecting Malaysian Undergraduate Students' Motivation in Improving English Proficiency in Academic Environments. In Higher Education Challenges in South-East Asia (pp. 35-73). IGI Global.

[10] Barua, A., \& Kumar Shiva Gubbiyappa, Hasnain Zafar Baloch, B. Das. (2014). Validation of Feedback Questionnaire on Flipped Classroom ( FC ) Activity. Computer Science Education Research Conference (CSER '14), 4(3), 22-29.

[11] Baytiyeh, H., \& Naja, M. K. (2017). Students' perceptions of the flipped classroom model in an engineering course: a case study. European Journal of Engineering Education, 42(6), 10481061. https://doi.org/10.1080/03043797.2016.1252905

[12] Braham, P. (2014). Qualitative and Quantitative Research. Key Concepts in Sociology, 129-136. https://doi.org/10.4135/9781473914704.n28

[13] Burhan, N. M., Tamuri, A. H., \& Nordin, N. M. (2015). Pedagogical usability for Digital Learning Content Module based on Blended Learning Strategy in Islamic Civilization and Asian Civilization Course. Tinta Artikulasi Membina Ummah, 1(2), 28-40.

[14] Chan, B., \& Keat, O. B. (2020). Factors Affecting Online Self-Regulated Learning In Yulin University, China. Solid State Technology, 5566-5574.

[15] Chan, S. Y., Lam, Y. K., \& Ng, T. F. (2020). Student's perception on initial experience of flipped classroom in pharmacy education: Are we ready? Innovations in Education and Teaching International, 57(1), 62-73. https://doi.org/10.1080/14703297.2018.1541189

[16] Conference, I., Engineering, C., View, U. K., Conference, I., Technologies, E., \& View, U. K. (2018). M . Sc in Marketing Management INDEPENDENT STUD Y “ Athens as an international tourism destination: An empirical investigation to the city' $s$ imagery and the role of local. 2018(September 2014). https://doi.org/10.13140/2.1.3023.1369

[17] Cuff, B. M. P. (2017). Perceptions of subject difficulty and subject choices: Are the two linked, and if so, how? (October). Retrieved from https://www.gov.uk/government/publications/students-subject-choices-at-gcseand-a-level

[18] Danker, B. (2015). Using Flipped Classroom Approach to Explore Deep Learning in Large Classrooms. IAFOR Journal of Education, 3(1), 171-186. https://doi.org/10.22492/ije.3.1.10

[19] Durkheim, E. (1999). Chapter - iii research methodology 3.1. (1985), 122-141.

[20] Eppard, J., \& Rochdi, A. (2017). A framework for flipped learning. Proceedings of the 13th International Conference on Mobile Learning 2017, ML 2017, 33-40.

[21] Evseeva, A., \& Solozhenko, A. (2015). Use of Flipped Classroom Technology in Language Learning. Procedia - Social and Behavioral Sciences, 206(November), 205-209. https://doi.org/10.1016/j.sbspro.2015.10.006

[22] Garner, B., \& Chan, M. (2019). Student Perceptions of Learning and Engagement in a Flipped Versus Lecture Course. Business and Professional Communication Quarterly, 82(3), 357-369. https://doi.org/10.1177/2329490619833173

[23] Gomez-Lanier, L. (2018). Building Collaboration in the Flipped Classroom: A Case Study. International Journal for the Scholarship of Teaching and Learning, 12(2). https://doi.org/10.20429/ijsotl.2018.120207

[24] Goyena, R., \& Fallis, A. . (2019). 済無No Title No Title. Journal of Chemical Information and Modeling, 53(9), 1689-1699. https://doi.org/10.1017/CBO9781107415324.004

[25] Hazaymeh, W. A., \& Altakhaineh, A. R. M. (2019). The effect of flipped classroom instruction on developing emirati EFL learners' pragmatic competence. International Journal of Learning, 
Teaching and Educational Research, 18(10), 89-111. https://doi.org/10.26803/ijlter.18.10.6

[26] Huang, C. K., \& Lin, C. Y. (2017). Flipping business education: Transformative use of teambased learning in human resource management classrooms. Educational Technology and Society, 20(1), 323-336.

[27] Igwenagu, C. (2016). Fundamentals of Research Methodology and Data Collection. LAP Lambert Academic Publishing, (June), $4 . \quad$ Retrieved from https://www.researchgate.net/publication/303381524_Fundamentals_of_research _methodology_and_data_collection

[28] Inan, N. K., Balakrishnan, K., \& Refeque, M. (2019). Flipping perceptions, engagements and realities: A case study. Turkish Online Journal of Distance EducatioInan, N. K., Balakrishnan, K., \& Refeque, M. (2019). Flipping Perceptions, Engagements and Realities: A Case Study. Turkish Online Journal of Distance Education, 20(1), 208-222. Https://Doi.Org/10.17718/Tojde.522, 208-222. https://doi.org/10.17718/tojde.522717

[29] Jamaludin, R., \& Osman, S. Z. M. (2014). The Use of a Flipped Classroom to Enhance Engagement and Promote Active Learning. Journal of Education and Practice, 5(2), 124-131. Retrieved from http://iiste.org/Journals/index.php/JEP/article/view/10648

[30] Keat, O. B., Rajaratnam, M. L., \& Yuniardi, M. S. (2020). The Profiling of PASS Cognitive Processing among Children with Learning Difficulties. International Journal of Psychosocial Rehabilitation, 24(05), 3205-3214.

[31] Nouri, J. (2016). The flipped classroom: for active, effective and increased learning - especially for low achievers. International Journal of Educational Technology in Higher Education, 13(1). https://doi.org/10.1186/s41239-016-0032-z

[32] Of, M. (2015). Malaysia Education Blueprint 2015-2025 (Higher Education) MINISTRY OF EDUCATION MALAYSIA. 2025. Retrieved from WWW.moe.gov.my

[33] Omid Sohrabi, \& Mohammad Mohammadi. (2014). The Impact of Flipped Model Instruction on Writing. International Journal of English Language and Translation Studies, 7(3), 111-122.

[34] Onojah, A. O., Olumorin, C. O., Adegbija, M. V., \& Babalola, T. O. (2019). Perception of Undergraduate Students on the Utilisation of Flipped Classroom for Learning in South-West Nigeria. Malaysian Journal of Distance Education, 21(1), 95-112. https://doi.org/10.21315/mjde2019.21.1.6

[35] Polytechnic, N. (2014). FLIPPED CLASSROOM FOR DIFFERENTIATED LEARNING Yap Tat Kwong and Pang Nai Kiat School of Information Technology, Nanyang Polytechnic, Singapore PANG_Nai_Kiat@nyp.edu.sg. (September).

[36] Pudin, C. S. J. (2017). Exploring a Flipped Learning Approach in Teaching Grammar for ESL Students. IJELTAL (Indonesian Journal of English Language Teaching and Applied Linguistics), 2(1), 51-64. https://doi.org/10.21093/ijeltal.v2i1.47

[37] Sams, A., \& Washington, O. (2012). Jonathan Bergmann.

[38] Shih, W. L., \& Tsai, C. Y. (2017). Students' perception of a flipped classroom approach to facilitating online project-based learning in marketing research courses. Australasian Journal of Educational Technology, 33(5), 32-49. https://doi.org/10.14742/ajet.2884

[39] Sinouvassane, D., \& Nalini, A. (2016). Perception of Flipped Classroom Model among Year One and Year Three Health Science Students. International Journal of Information and Education Technology, 6(3), 215-218. https://doi.org/10.7763/ijiet.2016.v6.687

[40] Sun, Z., Xie, K., \& Anderman, L. H. (2018). The role of self-regulated learning in students' success in flipped undergraduate math courses. Internet and Higher Education, 36(June 2017), 41-53. https://doi.org/10.1016/j.iheduc.2017.09.003

[41] Subon, F., Unin, N., \& Sulaiman, N. H. B. (2020). Self-Esteem and Academic Achievement: The Relationship and Gender Differences of Malaysian University Undergraduates. IAFOR Journal of Psychology \& the Behavioral Sciences, 6(1). https://doi.org/10.22492/ijpbs.6.1.03

[42] Tazijan, F., Murugan, A., Rahim, S. A., Mohamed, R., Mathai, E. J., \& Ismail, R. (2016). A Survey of Flipped Learning Approach in the ESL Context. Asian Journal of Education and E- 
Learning, $\quad$ 04(02), 2321-2454. $\quad$ Retrieved from https://www.ajouronline.com/index.php/AJEEL/article/viewFile/3562/2024

[43] Thi, T., Nguyen, K., Faculty, I. T., \& Nam, V. (2017). IJESMR I nternational J ournal OF E ngineering S ciences \& M anagement $R$ esearch IJESMR. 4(4), 2013-2018.

[44] Van Der Linden, S. (2014). On the relationship between personal experience, affect and risk perception: The case of climate change. European Journal of Social Psychology, 44(5), 430-440. https://doi.org/10.1002/ejsp.2008

[45] Razak, N. A., Yassin, A. A., \& Maasum, T. N. R. T. M. (2020). Formalizing Informal CALL in Learning English Language Skills. In Enhancements and Limitations to ICT-Based Informal Language Learning: Emerging Research and Opportunities (pp. 161-182). IGI Global.

[46] Yoshida, H. (2016). Perceived Usefulness of "Flipped Learning" on Instructional Design for Elementary and Secondary Education: With Focus on Pre-service Teacher Education. International Journal of Information and Education Technology, 6(6), 430-434. https://doi.org/10.7763/ijiet.2016.v6.727

[47] Zainuddin, Z., \& Halili, S. H. (2016). Flipped classroom research and trends from different fields of study. International Review of Research in Open and Distance Learning, 17(3), 313-340. https://doi.org/10.19173/irrodl.v17i3.2274

[48] Zainuddin, Z., Hermawan, H. D., Nuraini, F., \& Prayitno, S. M. (2019). Flipping the Classroom with a LMS: Designing A Technology-based learning Model for Teaching Islamic Studies Course in Indonesia. 13(3), 309-317. https://doi.org/10.11591/edulearn.v13i3.

About Authors:

Rafa Nurafida Binti Abdul Rahim, BA student of TESL at School of Education and Social Sciences, Management and Science University, Shah Alam, Malaysia. Her research interests include Second Language Learning and Special Education, Psychology and Pedagogy of Language Learning and Community Literacy.

Mohammad Ali Al-Saggaf, Ph.D is a Senior Lecturer of English and Linguistics at the School of Education and Social Sciences, Management and Science University (MSU), Shah Alam, Malaysia. His research interests include Cognitive \& Corpus Linguistics, Applied Linguistics (TESL), Language \& Intercultural Communication and Translation Studies. 